\title{
Hostage deaths put gas weapons in spotlight
}

Quirin Schiermeier

Is there such a thing as a 'non-lethal' chemical weapon? The tragic end to the hostage crisis in Moscow, in which 117 hostages were fatally poisoned by a gas intended to incapacitate the hostage-takers, has propelled this question to the top of the antiterrorist agenda.

Even now, the exact nature of the gas used by soldiers to free the 700 hostages, held in Moscow's Musical Theatre by Chechen gunmen with explosives strapped to themselves, is not entirely clear. Several days after the incident, Russian health minister Yuri Shevchenko said that the gas was an aerosol containing fentanyl, a potent and fast-acting opiate, which is used clinically as an anaesthetic and painkiller.

But fentanyl may have been only part of a mixture of gases used in the assault. Scientists at the Rechts der Isar University Hospital in Munich found traces of halothane, another general anaesthetic that is no longer widely used, in blood and tissue samples taken from two German hostages who survived the assault. "We are 100\% certain that we identified halothane," says Thomas Zilker, head of toxicology at Rechts der Isar. He was unable to detect fentanyl in the samples, but as it is rapidly metabolized, he says, it would in any case no longer have been detectable in the two hostages when they arrived in Munich two days after the attack.

\section{High risk}

Using fast-acting anaesthetics outside the operating theatre is highly risky regardless of their composition, scientists say. Both fentanyl and halothane have very narrow 'therapeutic windows', meaning that potentially fatal side-effects, including respiratory depression, occur at doses only slightly higher than those required for their therapeutic effects.

"Halothene and fentanyl are lousy agents, both with terrible effects on humans," says Alan Zelicoff, a senior scientist at the Center for National Security and Arms Control at Sandia National Laboratory in Albuqerque, New Mexico. "It was a grotesque assumption on the part of the Russian leadership that sloppy use of highly effective anaesthetics, pumped into a confined room full of weakened hostages, would not kill many people."

But under the circumstances of the crisis, Russia may not have had many alternatives, Zelicoff concedes. "I can think of no fast-acting agent that could be safely used as a knockout gas in such a situation," he admits.

The US Defense Department's Joint Non-Lethal Weapons Program supports an

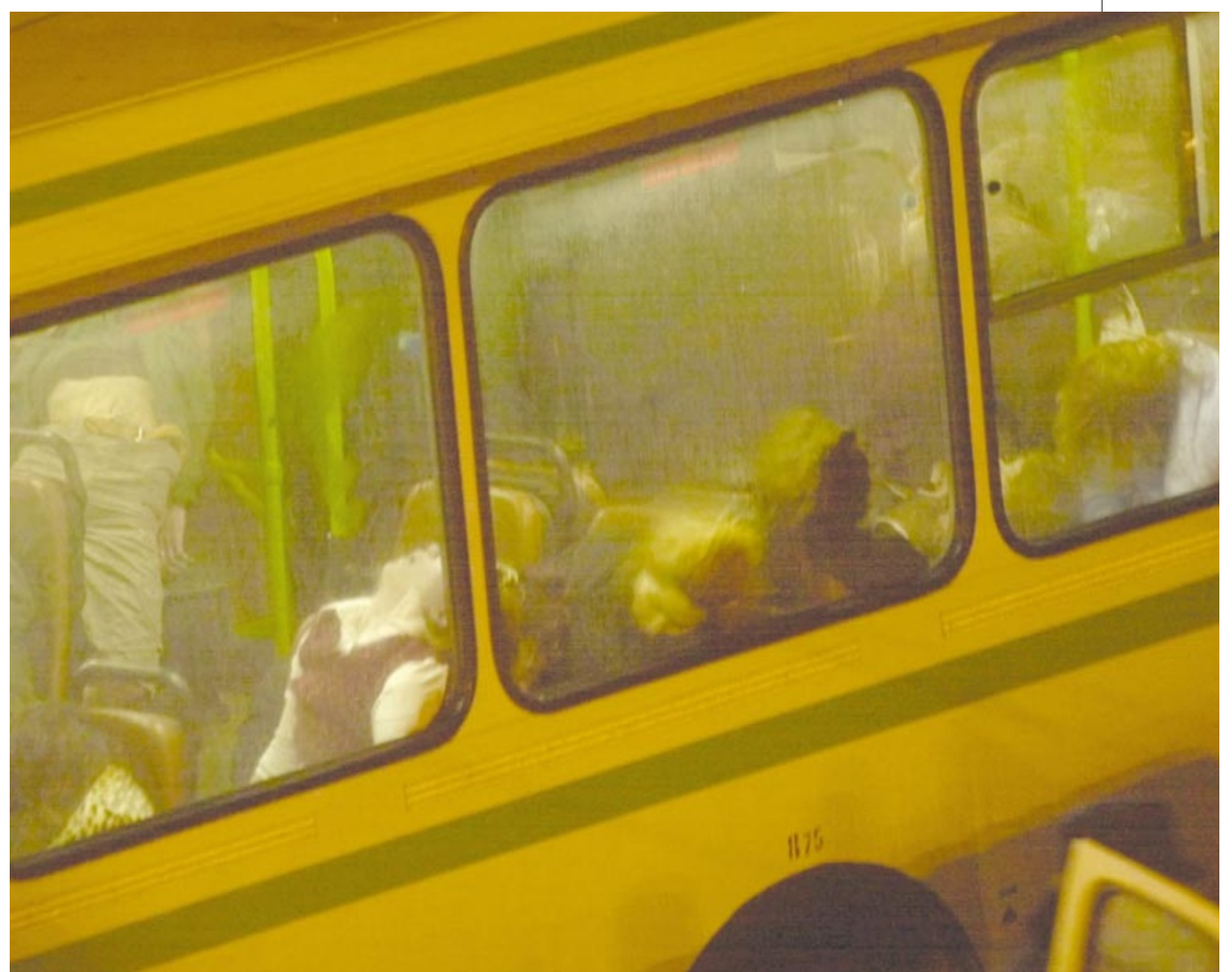

Liberated hostages are driven from the scene of Moscow's siege, in which 117 hostages were killed in a gas attack by Russian forces. Survivors were found to have inhaled potent anaesthetic compounds.

extensive drug-based weapons programme for law-enforcement purposes. At Pennsylvania State University's Institute for Emerging Defense Technologies, for example, researchers are investigating the potential of 'calmatives' based on benzodiazepines, a class of compounds that includes antianxiety drugs such as Valium. Such agents have wider therapeutic windows, so would be safer, says Zelicoff, but they would not have been fast-acting enough to have been useful in the Moscow situation.

\section{Banned substance?}

Non-lethal chemical weapons for lawenforcement purposes are allowed under the Chemical Weapons Convention (CWC). The CWC treaty, which bans the use of toxic chemicals for all military purposes, was ratified by Russia and the United States in 1997. The jury is still out on whether Russia violated the CWC in using chemical weapons against the Chechen gunmen - Russia's ongoing conflict with Chechnya has led to the assault being interpreted by many as military rather than civilian. "We are awaiting official information from the Russian federation," says a spokesman for the CWC Secretariat in The Hague.

But given the increasingly indistinct boundaries between military and civilian purposes, and the unavoidable risks associated with the mass distribution of any chemical, critics oppose the development and use of chemical agents in any circumstances.

"After Moscow, we have to rethink the medical implications of all 'non-lethal' agents, given the impossibility of getting an appropriate dose to all individuals in a large crowd," says Jan van Aken, a toxicologist who is head of the Hamburg-based office of the Sunshine Project, a US-German pressure group that deals with issues of biological and chemical warfare.

\section{Toxic toll}

Van Aken even challenges Zelicoff's assumption that calmatives would be safe. "Toxicologists estimate that even substances with a wide therapeutic window such as Valium would cause around 5\% casualties if used in concentrations high enough to knock out kidnappers," he says.

Zelicoff admits that non-lethal chemical weapons are a contentious issue. But outside the battlefield, chemical agents provide a humane alternative to conventional weapons, he argues. "It always comes down to the intent, of course," he says. "But please imagine a shot-down pilot surrounded by non-combatants: would it be more humane to disperse the crowd with tear-gas or with hotlead?" 